\title{
Constitutional Rewrite in Chile: Moving toward a Social and Democratic Rule of Law?
}

\section{Lisa Hilbink ${ }^{1}$}

Accepted: 25 October 2021 / Published online: 2 November 2021

(c) T.M.C. Asser Press 2021

Chile has often drawn the global spotlight, serving as a laboratory for some of the most dramatic political experiments of the past fifty-plus years. In 1970, adhering to well-established democratic rules of the game, Chileans elected Marxist president Salvador Allende, who sought to lead his country to socialism through legal means. Three years later, a military junta led by General Augusto Pinochet violently overthrew the Allende government, committing massive human rights violations that terrorized the population into submission, and proceeded to restructure the Chilean state and society along radical neoliberal lines, entrenching the model in a new constitution in 1980. After fifteen years of dictatorship, the democratic opposition managed to use some of the military regime's own constitutional rules and institutions to beat Pinochet in a plebiscite on his continued leadership, triggering a negotiated transition to civilian rule in 1989-1990. In the thirty years that followed, democratic political elites gradually reformed institutions and introduced social policies that helped lower the poverty level dramatically and raised the country's human development indicators into the "very high" bracket. However, inequality remained stubbornly high and middle-class status precarious, and the 1980 Constitution, despite several rounds of reforms, continued to place strict substantive and procedural limits on what democratic majorities could do to address these problems. Popular discontent with the economic system and the political institutions that maintained it thus grew, and in October 2019, boiled over in massive street protests referred to as the "social explosion" (estallido social). After a month of upheaval, elected officials from across the political spectrum negotiated a formal agreement, acceding to one of the key demands of the protestors: a democratic path to constitutional replacement. ${ }^{1}$ Chile is thus once again drawing international attention as it pursues an experiment in constitutional rewrite within democracy.

This special issue of the Hague Journal on the Rule of Law brings together topnotch analyses by experts on Chilean law and politics that dissect and reflect upon

\footnotetext{
1 Hilbink (2019), Hilbink and Salas (2019).

Lisa Hilbink

hilbink@umn.edu

1 Department of Political Science, University of Minnesota, Minneapolis, USA
} 
this unfolding process, providing information and insights for a global audience on several interrelated questions: What are the notable characteristics and achievements of Chile's constitutional renovation to date and what has made these possible? How and why is the Chilean constituent process similar to and distinct from other (recent) experiences of constitutional overhaul, in Latin America and beyond? Given current trends, what are reasons for optimism and what might complicate or frustrate the process? In this introduction, I offer a brief, synthetic overview of the responses to these questions from the six contributions to the special issue, informed and supplemented by my own past and ongoing research in Chile. ${ }^{2}$ Based on these combined perspectives, I argue that there are grounds for cautious optimism that Chileans may, at long last, move the country successfully in the direction of a social and democratic rule of law, ${ }^{3}$ providing the world a new and inspiring model of constitutional transformation.

Before proceeding, it is important to underscore that the subject of these articles is a moving target, a process that was just getting underway when the authors committed to the special issue and is subject to all the uncertainties and unexpected developments that characterize human affairs, particularly in the contemporary era. The analyses are thus necessarily open-ended, and any predictions quite general and speculative. The editors hope, nonetheless, that the special issue will provide a foundation of serious and original academic analysis and debate, serving as an important source for an international, English-speaking audience that may be unfamiliar with current debates and developments in Chile, and making use of comparative analysis to identify, and perhaps begin to explain, commonalities with and departures from constitutional rewrites in other countries.

\section{Key Features of Chile's Constitutional Renovation (Thus Far)}

The six articles in this special issue are rich in detail and illuminate numerous aspects of Chile's constitutional process to date. In this section, I discuss three key features that are highlighted in overlapping ways in the collection: (1) its emergence from below, as a demand articulated by protestors in the social uprising of 2019; (2) the broadly inclusive descriptive and ideological representation achieved in the Convention; and (3) the high level of procedural regulation of the process that both reflects and sustains negotiation and compromise between competing sectors.

First, Chile's constitutional rewrite was initiated as a response to a "violent, massive, and persistent social uprising" 4 in which, over the course of multiple weeks, millions of people took to the streets to protest inequality and exclusion, to demand respect for basic dignity and social rights, ${ }^{5}$ and, to insist on a "new constitution

\footnotetext{
${ }^{2}$ Much of this research is in collaboration with Valentina Salas, a PhD candidate at the University of Minnesota, to whom I am grateful for assistance and feedback during the preparation of this article.

3 On the concept of a social and democratic rule of law, see Lazcano (2020), and King (2018, p. 8).

4 See Couso in this issue.

5 As Suárez-Cao and Arenas-Catalán explain in their articles in this issue.
} 
now!" In this highly fragmented and largely leaderless movement, ${ }^{6}$ the call for a new constitution served as a unifying frame. It did so for several reasons. In addition to being a symbol of the dictatorship, the existing (1980) Constitution has served as a tool for entrenching the radical free-market model imposed by the military regime, effectively limiting the scope of majority decision making and preventing reforms that would strengthen the public sector and more equitably distribute wealth and power. $^{7}$ Average Chileans have become increasingly aware of how this "institutional straitjacket" 8 serves "to entrench privilege". 9 Citizens thus view constitutional change as necessary (even if not sufficient) to achieving a more just and democratic social order.

It should be noted that seeking to achieve change through institutional and legal means is a longstanding practice in Chile; politics has always been done in the idiom of law, whether under Allende, Pinochet, or in the post-Pinochet era. ${ }^{10}$ As one prominent left-leaning Chilean social scientist argued in 1974: "One of the most characteristic political realities of Chile is the importance of legality as a superior standard [instancia] to which all behaviors and the resolution of conflicts between people and institutions are referred.... Legality is the foundation of the government's legitimacy." "Moreover, replacement of the 1980 Constitution had been advocated by social movements, scholars, and political leaders for over a decade in Chile, ${ }^{12}$ and the administration of former President Michelle Bachelet led a creative but, due to a lack of support from the right-wing opposition, ultimately failed effort at constitutional rewrite in 2015-2017. ${ }^{13}$ This time, the push came from below, and from all sectors, including marginalized and often stigmatized populations, demonstrating that ordinary Chileans understand the importance of ensuring that those who would throw up barriers to change cannot take cover in the constitution.

A second, and related, key feature of Chile's constitutional rewrite is that sectors of the population whose perspectives have been historically under-represented or excluded from governance and policy making are being given voice in the process. Although prior to the social uprising, amendments to the Constitution and electoral reform had removed many of the institutional rules that guaranteed a veto on policies in the legislative process to the parties associated with the dictatorship and its economic model, ${ }^{14}$ the general public had become disenchanted with the political class, whom they perceived as out-of-touch with and insensitive to the reality of most of the population. To be sure, in the years leading up to the estallido, surveys registered

\footnotetext{
6 Suárez-Cao.

7 See Couso's contribution.

8 Suárez-Cao.

9 Arenas-Catalán.

10 See Hilbink, (2007), Hilbink (2009)

11 Arriagada (1974), p. 122.

12 Couso.

13 See Verdugo and Contesse (2018). As Couso states in his article for this special issue, only when faced with a "truly explosive situation" did the right-wing leaders agree to open a path to a new Constitution. (Couso).

14 See Couso.
} 
all-time lows in trust in political parties, and party identification, once very high in Chile, had declined to less than $20 \%$, leading many observers to describe the country as experiencing a crisis of representation. ${ }^{15}$ Meanwhile, however, both the feminist movement and indigenous communities (particularly the Mapuche, the largest indigenous nation in Chile) had begun mobilizing, and both had a powerful presence in the social uprising. Once the formal agreement on a path to a new constitution had been signed (more on this below), women organized to push for gender parity in the (eventual) constitutional drafting body. As Suárez-Cao explains in her article, having learned from the ineffective gender parity law that had gone into effect for congressional elections in 2017, they pressed for and won a set of rules that would ensure that neither gender could get less than $45 \%$ representation in the constituent body. ${ }^{16}$ It worked: Chile's will be the first constitution in the world drafted by an equal number of women $(49.5 \%)$ and men (50.5\%). The negotiation around indigenous representation, achieved through reserved seats, was more contentious, with left-wing parties advocating for 23 seats on top of the open 155, and right-wing parties starting with a bid for 8 of a total 155. In the end, 17 seats of 155 were reserved and filled by representatives of ten indigenous nations. One of these, Dra. Elisa Loncon, a Mapuche scholar, was elected President of the Convention by her colleagues, a development of high symbolic significance. ${ }^{17}$

In addition to this important gender and ethnic representation, the electoral rules adopted for the Convention allowed independents to compete, resulting in their winning 103 of 155 seats, or $66 \%$ of the total. ${ }^{18}$ This allowed newcomers from all walks of life and quite humble backgrounds to win seats in the assembly, ${ }^{19}$ while members of the traditional parties of both Left and Right had only a modest showing,-the right-wing coalition failing to achieve its expected one-third representation. The diverse body of fresh faces not only serves to "oxygenate the political system", ${ }^{20}$ but also effectively "eliminated the risk that regular Chileans" would perceive "that the traditional political parties 'captured' the Convention". ${ }^{21}$

A third defining feature of the process thus far is its procedural regulation, achieved through, and, in turn, helping to anchor, serious, often tense, but ultimately good-faith negotiation and compromise between those pushing for transformative change and those seeking to reduce or block it. As noted above, after a month of persistent and often violent street protests, congressional leaders from across the political spectrum engaged in 48 hours of marathon negotiations to hammer out an "Agreement for Social Peace and New Constitution," signed and published on November 15, 2019. ${ }^{22}$ As Prieto and Verdugo explain in this issue, in regards to

\footnotetext{
15 See Suárez-Cao.

16 Suárez-Cao.

17 Suárez-Cao.

18 See Couso and Negretto contributions to this special issue.

19 See Ríos Tobar (2021)

20 Suárez-Cao.

21 Couso.

${ }^{22}$ For an English translation of Agreement, see https://noticias.uai.cl/agreement-for-social-peace-and-anew-constitution/, accessed on October 23, 2021.
} 
constitutional change in Chile, the Left has a "revolutionary" approach that "appeals to social rights and the 'people' and directly emphasize[s] the use of the popular constituent power, including indigenous peoples and other minorities," while the Right has an "evolutive" approach emphasizing "legal continuity, institutional stability, and multiparty agreements that can give some minorities veto power over the outcomes." The radical version of each of these is mutually incompatible with the other, but the moderate versions can reach compromise. ${ }^{23}$ The November 15 th Agreement both "encapsulated core interests of both sides", ${ }^{24}$ and "represented crucial mutual concessions by the negotiating parties". ${ }^{25}$ Representatives of the Left accepted that each clause of the constitution and the rules of procedure would have to garner two-thirds support of voting members (potentially allowing for right-wing parties to block the adoption of provisions that they could not abide), while those from the Right accepted that failure to reach that threshold on any matter would not, as they would prefer, leave in place the relevant provision of the 1980 Constitution; in other words, the new constitution would be written on a "blank sheet" (hoja en blanco). ${ }^{26}$ The Agreement also provided that a technical committee would be appointed to amend the amendment rule of the 1980 constitution to allow for complete substitution of the document, and made it explicit that a constituent body could not interfere with the constituted public powers, change the quorum or procedural rules provided for in the Agreement, and had to dissolve when the constitution was complete. $^{27}$

The technical committee later reinforced these procedural rules and clarified that the only parameters for the content of the new charter were that "it must respect the republican nature of the Chilean state, its democratic regime, final and enforceable judicial decisions, and international treaties ratified by Chile that are in force". ${ }^{28}$ They also established that an ad hoc chamber of the Supreme Court, upon request of one quarter of the members of the Convention, would be empowered to review and void any breaches of the procedural rules, but, crucially, could not review the substance of decisions. ${ }^{29}$ In this regard, Couso contends that this combination of a "non-sovereign procedure coupled with a fairly sovereign capacity to decide on the content of the new Constitution" makes Chile a strong example of what Joel ColónRios calls a "procedurally regulated" process. ${ }^{30}$ Prieto and Verdugo label the Agreement "an interim constitution", which, by providing some boundaries to the uncertainty of the process, "has operated as a two-sided insurance." ${ }^{31}$ They note, however, that some of the more radical leftist factions (including the Communist Party and independents) that did not sign the Agreement but that won a sizable number of

\footnotetext{
${ }^{23}$ Prieto and Verdugo.

24 Prieto and Verdugo.

25 Couso.

26 As Couso, Prieto and Verdugo and Negretto's contributions to this issue highlight.

27 Couso.

28 See Negretto.

${ }^{29}$ Couso.

30 See Colón-Rios (2020), cited by Couso.

31 Prieto and Verdugo.
} 
seats in the Convention have announced that they do not view the Agreement as legitimate and will not be bound by it. For the moment, though, the moderates appear to have prevailed, and, as of this writing (mid-October 2021), the Convention has finished drafting the rules by which it will operate (reglamentos) and is moving into the phase of consultations and debates on content. ${ }^{32}$

\section{The Chilean Constituent Process (Thus Far) in Comparative Perspective}

The Chilean constitutional rewrite, emerging as it has out of a crisis of representation, high levels of popular mistrust in existing institutions, antipathy toward the political class, and a clamor for social rights, has led some to assume, or to fear, that Chile is following the path taken by Venezuela in 1999, Ecuador in 2008, and Bolivia in 2009. To be sure, the "revolutionary" approach of the Chilean Left described by Prieto and Verdugo certainly has echoes of those constitutional transitions to "twenty-first century socialism". ${ }^{33}$ However, through a juxtaposition of the Venezuelan and Chilean cases, García Soto, Martínez Meucci and Sánchez Urribarrí illuminate crucial differences.

The constitutional rewrite in Venezuela followed over a decade of economic crisis, social strife and political instability, and was led by the charismatic and antiestablishment new President, Hugo Chávez. ${ }^{34}$ In Chile, by contrast, the process was, as previously noted, demanded from below in an intense popular revolt, to which a broad swath of congressional leaders responded with an agreement that can be understood as an interim constitution. ${ }^{35}$ This "represented a consensual effort to "reconstitute the state...via a constitutional, legal pathway". 36

In Venezuela, Chávez employed a quintessential populist discourse, advancing "the idea of the people as true sovereign and legitimate source of "constituent power" "and pursuing the constitutional rewrite as a vehicle of revenge of the people against the country's elites. On the day of his inauguration, he thus issued a decree calling for a referendum to rewrite the constitution, setting off a rushed process in an environment of extreme polarization with a "fragmented opposition landscape." This resulted in Chávez's candidates' winning 124 out of 131 seats in the Constituent Assembly, despite garnering only $62 \%$ of votes cast, definitively sidelining the previous regime actors. ${ }^{37}$ This contrasts with Chile, where "conditions were ripe for the emergence of radical populism" and "contestation against the political elite could have driven a strongman to power, but did not". ${ }^{38}$ Instead, elected leaders of

\footnotetext{
32 See Heiss (2021). For the text of the procedural "convenios" themselves, see https://www.chileconve ncion.cl/ (Last accessed October 21, 2021).

33 See García Soto, Martínez Meucci and Sánchez Urribarrí’s contribution.

34 García Soto, Martínez Meucci and Sánchez Urribarrí.

35 Prieto and Verdugo.

36 García Soto, Martínez Meucci and Sánchez Urribarrí.

37 García Soto, Martínez Meucci and Sánchez Urribarrí.

38 Suárez-Cao.
} 
the Left and Right negotiated a democratic and institutional way out of the crisis that responded to the public's demand for greater participation, and adjustments to electoral rules that already provided for strongly proportional representation produced a Constitutional Convention with a "wide range of representatives and views", 39 in which no one party can control the outcome. ${ }^{40}$

A last major contrast between the two cases is that regulation of the constitutional process "was absent and ad-hoc" in Venezuela, where "institutional or legal restrictions [came] second to the 'voice of the people' and Chávez's will as their legitimate leader", ${ }^{41}$ whereas the process in Chile, as noted above, has been characterized by a high level of procedural regulation, more reminiscent of the South African experience of 1993-1996. ${ }^{42}$ Indeed, taking a broad comparative perspective, Negretto notes that the 13 new articles of the December 2019 amendment to the 1980 constitution that establish the rules to structure the replacement of the document "count among the most detailed regulations of this kind."43

Negretto's article puts the Chilean experience (to date) in a more general comparative framework of constitution making in democratic regimes over the past century. He contends that three central characteristics of the process (so far), namely its legal continuity, its inclusive representation and decision making, and its mechanisms of popular participation, "correlate positively with successful comparative experiences of democratic constitutional replacement". ${ }^{44}$ He highlights the strong support that comparative empirical studies have found, in particular, for the importance of inclusive representation and decision making in the constitution-making body, which "induces the adoption of institutions that protect opposition forces" and ultimately "enhanc[es] the incentives of the main political actors to abide by the constitution" once it is in place. ${ }^{45} \mathrm{He}$ further notes that proportional electoral formulae and/or qualified majority rules to approve the constitution are present in most such cases. Chile has both, which may bode well for the success of the process, but also poses some challenges, as will be elaborated in the next section.

\section{Reasons for Optimism and Potential Complications}

As the discussion to this point indicates, key characteristics of the Chilean constitution making process so far, particularly when considered in comparative perspective, give a number of reasons for optimism that it will continue to advance constructively and produce a charter that will enable legitimate, effective, and stable democratic governance. Each of these come with caveats or qualifiers, however.

\footnotetext{
39 García Soto, Martínez Meucci and Sánchez Urribarrí.

40 As Suárez-Cao and Negretto highlight in their contributions to this issue.

41 García Soto, Martínez Meucci and Sánchez Urribarrí.

42 Couso.

43 Negretto.

44 Negretto.

45 Negretto.
} 
To begin, the November 15, 2019 Agreement has effectively anchored the process, providing the "two-way insurance" that has kept moderates on both sides from reneging on their commitment, and allowing further procedural regulations to be negotiated and accepted in good faith, by the technical commission, the Congress, and the Convention itself. ${ }^{46}$ This is not to say that the process has been entirely harmonious; certainly there have been some worrisome moments, most notably when Convention representatives of the radical Left (List of the People and the Communist Party), uniting under the label "Voice of the People," declared that they do not feel bound by the terms of the Agreement. ${ }^{47}$ Given the poor showing of the rightwing parties in the elections to the Convention, the Left needs to take extra care to keep their political adversaries in the game; reneging on the foundational terms of the Agreement (the "interim Constitution") would spell disaster for the process. ${ }^{48}$ The outcome of the presidential elections later this year (first round, November 21, 2021, and second (run-off) round, December 19, 2021) is of no small consequence for how things could unfold, ${ }^{49}$ although the support for moderates in the primaries in July, including the social democrat and institutionalist, Gabriel Boric, was a hopeful sign. 50

As noted in the previous section, the inclusive representation and decision-making rules for the Convention, and the fact that the composition of the drafting body is highly diverse and fragmented, are also cause for optimism. For starters, no party, coalition, or movement commands an automatic two-thirds majority, nor an automatic one-third minority, which would allow them to hijack decision making. ${ }^{51}$ Each article of the new charter must be negotiated and garner support from two-thirds of delegates, and it may be different (cross-cutting) combinations each time. Power is thus dispersed in the drafting process, ${ }^{52}$ leading, in all likelihood, to decisions that aim at power sharing (at different levels and in different ways), rather than concentrating power. ${ }^{53}$ Moreover, as Suárez-Cao contends, "the diversity of the Convention is an asset that can rebuild the legitimacy of representative institutions." 54 During the uprising, and through their strong support (almost 80\%) in the October 2020 plebiscite for the option of a constitution drafting body separate and independent from the sitting legislature, the public signaled strongly that they wanted a new constitution written not by politicians, whom they perceive to be self-dealing, but by people in touch with average citizens. This is largely what they got. Moreover, the Convention is creating mechanisms that will allow citizens, residents, and even children to propose constitutional initiatives, as well as implementing the right of

\footnotetext{
46 Prieto and Verdugo.

47 Prieto and Verdugo, Couso.

48 Prieto and Verdugo.

49 García Soto, Martínez Meucci and Sánchez Urribarrí.

50 Couso.

51 Couso.

52 Negretto.

53 Suárez-Cao.

54 Suárez-Cao.
} 
indigenous peoples to prior, free, and informed consultation in the process. ${ }^{55}$ Of course, expanding representation and participation also brings challenges. Couso cautions that high fragmentation of the Convention translates to significant coordination costs to pass each clause of the new charter: "that very fragmentation-combined with the two thirds quorum-represents the single most important hurdle to agree on a text to be submitted to the Chilean people for ratification." 56 Suárez-Cao drives this point home, reminding readers that "a good constituent process is also a finished constituent process." 57

It is perhaps fortunate, then, that there is a solid consensus within the Convention, and among the general public, around some substantive matters-offering another reason for optimism. This substantive consensus is clearest around the expansion of social and participatory rights, ${ }^{58}$ demands for which were at the heart of the social uprising, but which long pre-dated 2019. Couso notes that Chileans had long felt economically insecure "due to an economic model where access to good-quality healthcare and education, as well as the likelihood of having a decent pension, [have] depended on securing and maintaining a job." ${ }^{59}$ Key demands of the uprising included an end to the privatized pension system and to the "economically segregated" healthcare system through the introduction of "a universal public health service", 60 as well as mechanisms of direct democracy to devolve power from the centralized control of political parties and national representative institutions. ${ }^{61}$ Negretto points out that the (blocked) proposal for a new constitution under former President Bachelet "incorporated the right to health and education as justiciable rights and granted the option for a public pension system" as an alternative to the existing private one. Arenas-Catalán reminds us that this would not be a radical new departure but would in fact be returning the country to the more solidaristic principles of the 1925 Constitution, which the military regime forcibly replaced with the 1980 charter. ${ }^{62}$ In addition, there is a "transversal consensus on the need for decentralization", 63 and with $70 \%$ of the delegates to the Convention elected in districts outside the metropolitan area of Santiago, "the influence of regional interests is likely to be important in the design of the new constitution". ${ }^{64}$ Moreover, with the reserved seats for indigenous peoples and the commitment to honoring their right to prior consultation, there appears to be strong support for declaring Chile a plurinational state and for enhancing the cultural, legal, and political autonomy of those

\footnotetext{
55 For an overview of citizen participation in the Convention thus far, see: https://plataformacontexto.cl/ contexto_factual/de-la-ciudadania-a-la-convencion-las-propuestas-enviadas-para-considerar-en-el-traba jo-constituyente/ (Last Accessed October 24, 2021).

56 Couso.

57 Suárez-Cao.

58 Negretto.

59 Couso.

60 Arenas-Catalán.

61 Negretto.

62 Arenas-Catalán.

63 Suárez-Cao.

64 Negretto.
} 
communities. ${ }^{65}$ While Arenas-Catalán correctly points to "the threats that could feed from" a failure to meet the expectations of the mobilized population around these substantive constitutional provisions, Negretto voices a longer-term, pragmatic concern that an excessively negative or reactive design, in which power is radically decentralized and diffused and justiciable rights proliferate, could make effective government more difficult and/or may prove insufficient to solve the structural problems that drove the uprising.

For the moment, though, ordinary Chileans continue to express strong interest in the constituent process and a belief that it will change their lives for the better-a finding from my own research. ${ }^{66}$ In an original, nationally-representative survey conducted in the two months between the May 2021 elections for the Constitutional Convention and the first meeting of the Convention in early July $2021,{ }^{67}$ my collaborator, Valentina Salas, and I found that large majorities of the Chilean population not only feel the process of constitutional change is important to them and say they will follow the drafting process closely (75\% agree or strongly agree on both counts), ${ }^{68}$ but they also express optimism that the new constitution will make a positive difference in their lives (63\% overall, including $61 \%$ of low- and lower-middle income respondents, and a striking 74\% of 18-29 year-old respondents). ${ }^{69}$ The relevance of these high levels of popular support should not be underestimated.

\section{Conclusion}

The ongoing constitutional rewrite in Chile is just the latest in a country whose political experiments and innovations have earned it an outsized place in the global imagination. The articles in this special issue, whose main claims I have sought to distill and synthesize here, offer outstanding accounts and analyses that, with different foci and from distinct perspectives, help contextualize and explain the trajectory of Chile's constituent process over the past two years. While all the authors recognize the challenges and potential pitfalls of this still unfolding process, their

\footnotetext{
65 Negretto.

66 This research was generously funded by grants from the Human Rights Initiative, the Human Rights Lab, and the College of Liberal Arts at the University of Minnesota and was approved by the IRB as STUDY00012629.

67 The data are based on a random sample of $\mathrm{N}=1,067$ adults ( 18 years and older) that live in urban areas across the 16 regions in Chile. A local research firm, Guernica, helped us to implement the telephone survey between May 20th and June 30th, 2021 using a sampling frame of telephone numbers $(\mathrm{N}=9,761)$, representative at the national and regional levels. The sample was composed of $47.4 \%$ males and $52.6 \%$ females, and the mean age of respondents was 48 years.

68 The questions in Spanish (the 23rd and 26th questions in the survey, respectively) asked respondents to rate their level of agreement or disagreement with the statement: "The constitutional change process underway in the country is important for my daily life" ("El proceso en curso de cambio constitucional en el país es importante para mi vida cotidiana") and "I will closely follow the drafting process of the new constitution ("Seguiré de cerca el proceso de redacción de la nueva constitución").

69 This was the 24th question in the survey, in which respondents were asked to rate their level of agreement or disagreement with the statement: "I believe the new constitution will improve my daily life." which in Spanish read, "Yo creo que la nueva constitución mejorará mi vida cotidiana.".
} 
pieces together indicate that, more than thirty years after the transition to civilian rule, there are reasons to be cautiously optimistic that Chile may be on its way not only to a definitive end of control by the 'dead hand' of the authoritarian past, but also, by adhering to a "democratic, participatory and institutional" approach, ${ }^{70}$ to establishing itself as a model for the construction of a social and democratic rule of law, in Latin America and beyond.

As an outside observer and as a comparative political scientist, I want to close by underscoring how remarkable the process has been so far. In an era in which, globally, so many democracies are eroding due to (often) elite-fed polarization and the abandonment of the fundamental norms that make democratic governance possible, Chileans have demonstrated an extraordinary dedication to and capacity for negotiation, compromise, and consensus-building, as well as an impressive commitment to working through institutions and in accordance with procedural rules. This is not to dismiss the violence and destruction that have been a significant element of the process; but, compared to other countries in the region and in the world, the dominant display of civic spirit and responsible conduct by elites and ordinary citizens alike at each step of the process has been quite stunning. ${ }^{71}$ Let us hope, then, that, just as "the horizons of Chile's political imagination have been considerably broadened" in the years leading up to this process, ${ }^{72}$ the Chilean constitutional process will serve to broaden what observers around the world imagine possible in these trying times.

\section{References}

Arriagada G (1974) De la “Via Chilena” a la "Via Insurrecional.” Editorial del Pacífico, Santiago

Colón Ríos J (2020) Constituent power and the Law. Oxford University Press, Oxford

Heiss C (2021) Where the rubber meets the road: Chile's constitutional convention decides its rules of procedure, ConstitutionNet, Voices from the Field, Sept. 25, 2021. https://constitutionnet.org/news/ where-rubber-meets-road-chiles-constitutional-convention-decides-its-rules-procedure. Accessed 22 Oct 2021

Hilbink L (2007) Judges beyond politics in democracy and dictatorship. Cambridge University Press, New York

Hilbink L (2009) The constituted nature of constituents' interests: historical and ideational factors in judicial empowerment. Polit Res Q 62(4):781-797

Hilbink L and Salas V (2019) Path to a new constitution in Chile: how the unthinkable became the inescapable, ConstitutionNet, Voices from the Field, Nov. 27, 2019. http://constitutionnet.org/news/ path-new-constitution-chile-how-unthinkable-became-inescapable. Accessed 22 Oct 2021

Hilbink L (2019) New constitution or nothing! The promise and pitfalls of Chile's constitutional moment, Int'1 J. Const. L. Blog, Nov. 24, 2019. http://www.iconnectblog.com/2019/11/new-constitution-ornothing-the-promise-and-pitfalls-of-chiles-constitutional-moment/. Accessed 22 Oct 2021

King J (2018) Social rights in comparative constitutional theory. In Comparative Constitutional Theory. Edward Elgar Publishing, Cheltenham, p 8

\footnotetext{
70 This was the guiding phrase that President Michelle Bachelet advanced in her (frustrated) attempt to lead a constitutional rewrite in 2015-17.

71 García Soto, Martínez Meucci and Sánchez Urribarrí note something similar in the conclusion of their article.

72 Arenas-Catalán.
} 
Lazcano AJM (2020) Los derechos humanos en el estado social y democrático. Revista Eletrônica do Curso de Direito da UFSM, 15.2: 48166. https://periodicos.ufsm.br/revistadireito/article/view/ 48166/pdf. Accessed 21 Oct 2021

Ríos Tobar M (2021) Chile's Constitutional Convention: a triumph of inclusion, UNDP in Latin America and the Caribbean Blog, June 3, 2021. https://www.latinamerica.undp.org/content/rblac/en/home/ blog/2021/chile-s-constitutional-convention--a-triumph-of-inclusion.html. Accessed 22 Oct 2021

Verdugo S and Contesse J (2018) The rise and fall of a constitutional moment. Lessons from the Chilean experiment and the failure of Bachelet's project, Int'1 J. Const. L. Blog, Mar. 13, 2018. Accessed on Oct 21, 2021 at: http://www.iconnectblog.com/2018/03/the-rise-and-fall-of-a-constitutionalmoment-lessons-from-the-chilean-experiment-and-the-failure-of-bachelets-project

Publisher's Note Springer Nature remains neutral with regard to jurisdictional claims in published maps and institutional affiliations. 